DOI: $10.31933 / \mathrm{JIMT}$

Received: 23 Agustus 2020, Revised: 10 September 2020, Publish: 22 September 2020

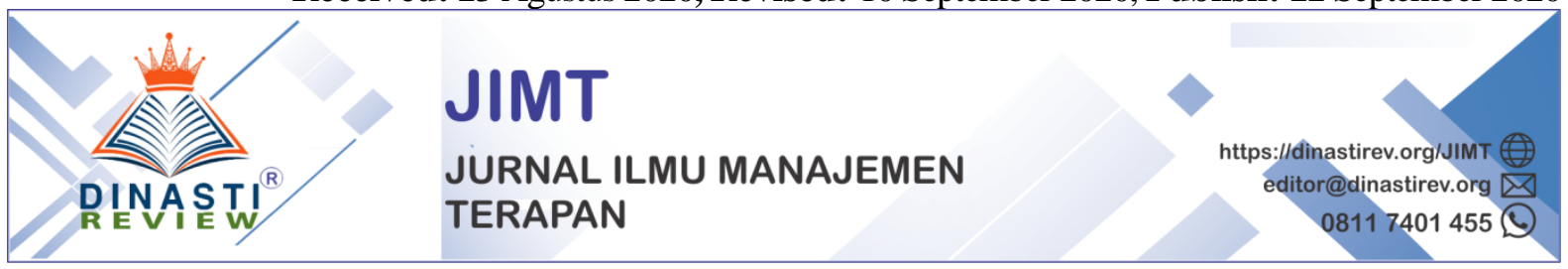

\title{
PENGARUH TINGKAT LITERASI KEUANGAN TERHADAP PENGELOLAAN KEUANGAN PADA PELAKU UMKM KECAMATAN CINERE, DEPOK
}

\section{Pusporini $^{1)}$}

${ }^{1)}$ Universitas Pembangunan Nasional Veteran Jakarta, Indonesia, agnirizkitaa@gmail.com

\section{Corresponding Author: First Author}

Abstrak: Penelitin ini bertujuan untuk mengetahui seberapa besar tingkat literasi keuangan serta pengaruhnya terhadap pengelolaan keuangan UMKM Kecamatan Cinere Depok. Penelitian ini merupakan penelitian kuantitatif. Dalam penelitian ini perhitungan besar sampel (sample size) yang diambil sebanyak 50 responden yang ikut serta dalam penelitian ini. Variabel yang digunakan dalam penelitian ini meliputi variabel independen, yaitu literasi keuangan, dan variabel dependen, yaitu pengelolaan keuangan. Instrumen yang digunakan dalam penelitian ini adalah kuesioner dengan Skala likert membedakan antara jawaban 1-5. Metode analisis menggunakan analisis PLS. pada hasil penelitin ini menunjukkan bahwa Literasi Keunagan berpengaruh signifikan terhadap pengelolaan keuangan UMKM di Kecamatan Cinere Depok

Kata Kunci: Literasi Keuangan, Pengelolaan Keuangan, UMKM

\section{PENDAHULUAN}

Mengatur atau mengelola keuangan usaha dan bisnis secara efektif merupakan sebuah metode untuk menjaga laju atau aliran dana perusahaan agar tidak terjadi kebocoran yang berujung kerugian finansial. Pengelolaan keuangan (money management) pada umumnya merupakan suatu kegiatan pengelolaan dana dalam kehidupan sehari-hari yang dilakukan oleh seorang individu atau kelompok yang memiliki tujuan untuk memperoleh kesejahteraan keuangan (financial welfare).

Dalam mencapai kesejahteraan tersebut, dibutuhkan pengelolaan keuangan yang baik sehingga uang bisa digunakan sesuai dengan kebutuhan dan tidak dihambur-hamburkan. Untuk bisa menerapkan proses pengelolaan keuangan yang baik, maka dibutuhkan tanggung jawab keuangan untuk melakukan proses pengelolaan uang dan aset lainnya dengan cara yang dianggap positif (Ida dan CinthiaY.D., 2010).

Proses pengelolaan keuangan merupakan suatu aktivitas yang sangat penting untuk dilakukan oleh para pelaku usaha, termasuk bagi pelaku ekonomi rakyat, yang mayoritas berskala Usaha Mikro, Kecil, dan Menengah (UMKM). UMKM merupakan suatu bentuk usaha kecil masyarakat yang pendiriannya berdasarkan inisiatif seseorang. Menurut Kerry (2010), peranan UMKM sangat strategis dalam perekonomian sebagai salah satu kekuatan 
pendorong utama dalam pembangunan ekonomi.

UMKM memiliki kontribusi yang besar terhadap pendapatan daerah maupun pendapatan negara, dan juga sangat berperan dalam mengurangi tingkat pengangguran karena dari sifatnya yang padat karya, jenis usaha ini mampu menyerap banyak tenaga kerja yang masih menganggur. Usaha Mikro Kecil dan Menengah (UMKM) memiliki potensi tumbuh kembang yang besar dalam meningkatkan taraf hidup rakyat banyak. Hal ini ditunjukkan oleh keberadaan UMKM yang telah mencerminkan wujud nyata kehidupan sosial dan ekonomi bagian terbesar dari rakyat Indonesia.

Sebagai salah satu komponen dalam industri nasional, Usaha Mikro, Kecil, dan Menengah (UMKM) berperan penting dalam perekonomian nasional, penyerapan tenaga kerja, pemerataan distribusi hasil-hasil pembangunan, dan penanggulangan kemiskinan. Data statistik menunjukan bahwa jumlah unit usaha kecil mikro dan menengah (UMKM) mendekati angka 99,98\% dari total unit usaha di Indonesia dengan kontribusi sebesar 56\% dari total PDB di Indonesia. Hal ini mencerminkan tingginya signifikansi peran UKM bagi pemerataan ekonomi Indonesia (Layyinaturrobaniyah dan Muizu, 2017).

Pentingnya peranan Usaha Mikro, Kecil dan Menengah (UMKM) bagi perekonomian nasional dilihat pada saat krisis ekonomi, UMKM terbukti mampu menampung 99,45 persen dari total tenaga kerja atau 73,24 juta tenaga kerja. Kontribusi yang diberikan oleh pelaku UMKM pada kondisi krisis ekonomi dapat dinilai sebagai penopang dalam proses pemulihan perekonomian nasional, dipandang dari laju pertumbuhan ekonomi nasional maupun dalam peningkatan kesempatan kerja.

Pengelolaan keuangan penting untuk diterapkan pada UMKM. Menurut Ediraras (2010) bisnis UMKM yang keuangannya dikelola dan diinformasikan secara transparan dan akurat akan memberikan dampak positif terhadap bisnis UMKM itu sendiri. Dampak positif pengelolaan keuangan inilah, yang menjadi suatu faktor kunci keberhasilan UMKM dan dapat digunakan untuk mempertahankan keberlanjutan usahanya.

Pengelolaan keuangan menjadi suatu masalah dalam UMKM karena pemilik UMKM mengabaikan pentingnya pengelolaan keuangan khususnya berkaitan dengan penerapan kaidah-kaidah pengelolaan keuangan dan akuntansi yang benar. Masalah ini biasanya timbul dikarenakan pengetahuan dan informasi pelaku Usaha Mikro mengenai akuntansi sangat terbatas, latar belakang pendidikan para pelaku Usaha Mikro juga mempengaruhi pengetahuan para pelaku Usaha Mikro.

Menurut Setyorini, et.al. (2010) menyatakan pengelolaan keuangan menjadi salah satu aspek penting bagi kemajuan perusahaan. Pengelolaan keuangan dapat dilakukan melalui akuntansi. Akuntansi merupakan proses sistematis untuk menghasilkan informasi keuangan yang dapat digunakan untuk pengambilan keputusan bagi penggunanya. Sepanjang Usaha Mikro Kecil Menengah (UMKM) masih menggunakan uang sebagai alat tukarnya, akuntansi sangat dibutuhkan oleh UMKM.

Beberapa pelaku UMKM mengatakan bahwa tanpa akuntansi pun perusahaan tetap berjalan lancar dan selalu memperoleh laba (Setyorini, et.al., 2010). Banyak pelaku UMKM merasa bahwa perusahaan mereka berjalan normal namun sebenarnya UMKM tersebut tidak mengalami perkembangan. Ketika mereka mendapatkan pertanyaan mengenai laba yang didapatkan setiap periode, mereka tidak bisa menunjukkan dengan nominal angka melainkan 
dengan aset berwujud seperti tanah, rumah, atau kendaraan.

Lebih lanjut, aset tersebut didapatkan tidak hanya dengan dana perusahaan tetapi terkadang ditambah dengan harta pribadi. Aset tersebut terkadang juga bukan digunakan untuk perusahaan namun digunakan untuk kepentingan pribadi dan tidak terdapat pencatatan ataupun pemisahan di antara keduanya. Pernyataan di atas menunjukkan rendahnya literasi atau pemahaman keuangan oleh para pelaku UMKM. Oleh karena itu, diperlukan upayaupaya strategis guna meningkatkan kinerja dan keberlangsungan UMKM. Salah satu cara yang dapat dilakukan adalah dengan memperkaya pengetahuan pelaku UMKM terhadap pengetahuan keuangan sehingga pengelolaan dan akuntabilitasnya bisa dipertanggungjawabkan dengan lebih baik sebagaimana layaknya perusahaan besar (Aribawa, 2016: 3).

Memahami dan memanfaatkan literasi keuangan, merupakan hal vital untuk mendapatkan kehidupan yang lebih sejahtera, dan berkualitas. Terlebih lagi jika seseorang dapat mengelola keuangan dengan pintar, diantaranya dapat mengelola kredit dan berinvestasi dengan cerdas. Hal tersebut tentunya sangat bermanfaat untuk kelangsungan hidup di masa depan, diantaranya dapat digunakan untuk mendanai sekolah atau pendidikan tinggi, asuransi, dan program lainnya.

Mengenal lebih jauh tentang keuangan dan cara pemanfaatannya tentu sangat penting terutama di kalangan pelaku usaha atau wirausaha. Pemahaman dan cara mengelola serta memanfatkan keuangan sangatlah penting karena hal tersebut sangat berguna dan banyak manfaatnya bagi mereka yang membuka usahanya sendiri ataupun bergerak di bidang Usaha Mikro Kecil dan Menengah (UMKM) untuk dapat meningkatkan pendapatannya.

Perilaku keuangan adalah isu yang paling banyak di bahas saat ini. Yang berkaitan dengan Perilaku keuangan masyarakat Indonesia yang cenderung konsumtif kemudian menimbulkan berbagai perilaku keuangan yang tidak bertanggung jawab lainnya seperti kurangnya kegiatan menabung, investasi, perencanaan dana darurat dan penganggaran dana untuk masa depan, sehingga seringkali individu dengan pendapatan yang cukup saja masih mengalami masalah finansial.

Saat ini tingkat literasi keuangan yang terjadi pada Usaha Mikro Kecil dan Menengah (UMKM) di Indonesia masih sangat rendah. Berdasarkan data Otoritas Jasa Keuangan (OJK) pada Agustus 2014, bahwa penyaluran kredit untuk UMKM baru sebesar 18\% dari total kredit (hanya Rp635 Triliun dari total kredit Rp3.500 Triliun). Menurut pihak OJK nilai tersebut sangat sedikit jika dibandingkan jumlah pelaku usaha UMKM. Tingkat literasi keuangan pada kelompok UMKM hanya sebesar 15,68\% hasil survey yang dilakukan oleh OJK tahun 2013. Data Bank Indonesia tahun 2011-2012, menunjukkan bahwa jumlah UMKM di Indonesia mencapai 55 juta UMKM. Para pelaku usaha masih rendah dalam memanfaatkan layanan perbankan dalam mengembangkan usaha miliknya. Hal ini menunjukkan hanya sekitar 8 juta UMKM yang telah menggunakan produk perbankan.

Dari hasil survey "Penelitian Profil UMKM di Indonesia" yang dilakukan Bank Indonesia pada tahun 2005 antara lain teridentifikasi bahwa salah satu kendala perbankan dalam menyalurkan kredit ke UMKM adalah keterbatasan informasi perbankan mengenai UMKM yang potensial dan kelayakan (eligibility) UMKM tersebut. Rendahnya tingkat literasi keuangan pada UMKM berdampak terhadap penyerapan kredit oleh sektor perbankan. 
Ada 4 kendala besar yang harus dihadapi para pelaku UMKM yaitu keterbatasan modal kerja, SDM, Inovasi produk dan teknologi serta pemasaran. Namun yang sangat banyak terjadi di lapangan masalah permodalan adalah alasan klise banyak UMKM tidak berkembang. Tidak semua golongan masyarakat, khususnya golongan masyarakat berpenghasilan rendah dapat memanfaatkan produk dan layanan jasa keuangan.

Berdasarkan rumusan The Association of Chartered Certified Accountants (2014) literasi keuangan mencakup pengetahuan mengenai konsep keuangan, pemahaman komunikasi mengenai konsep keuangan, kemampuan mengelola keuangan pribadi ataupun perusahaan serta kemampuan dalam pengambilan keputusan keuangan pada situasi-situasi tertentu. Melalui literasi keuangan yang baik, pelaku UMKM dapat memanfaatkan pengetahuan keuangannya tersebut dalam proses pengambilan keputusan yang tepat bagi usaha yang sedang mereka kelola untuk mencapai tujuan dan mempertahankan keberlangsungan hidup usaha (Muraga dan John, 2015; Draxler, Fischer, dan Schoar, 2014).

Di Indonesia, tingkat literasi keuangan penduduk Indonesia masih tergolong rendah apabila dibandingkan dengan negara-negara berkembang lainnya. Persentase masyarakat Indonesia yang memiliki pengetahuan, kemampuan, serta keyakinan pengelolaan keuangan dengan baik (well literate) hanya sebesar $21.8 \%$ saja. Berdasarkan data Otoritas Jasa Keuangan pada tahun 2013 sebagai pembanding, Indonesia tertinggal jauh dari Malaysia yang memiliki tingkat literasi keuangan well literate sebesar 66\%, Singapura sebesar 98\%, dan Thailand dengan 73\% (Bank Negara Indonesia, 2014). Data OJK pada tahun 2016 menunjukkan sedikit peningkatan pada tingkat literasi keuangan masyarakat Indonesia yang beranjak naik ke angka 29,6\%. Hasil survei OJK yang melakukan stratifikasi tingkat literasi keuangan berdasarkan wilayah provinsi pada Gambar dibawah ini menunjukkan Provinsi DKI Jakarta memiliki tingkat literasi keuangan tertinggi sebesar 40\%, diikuti oleh Jawa Barat dengan nilai 38,7\%, dan Papua Barat menjadi provinsi dengan tingkat literasi keuangan paling rendah dengan nilai $19.27 \%$.

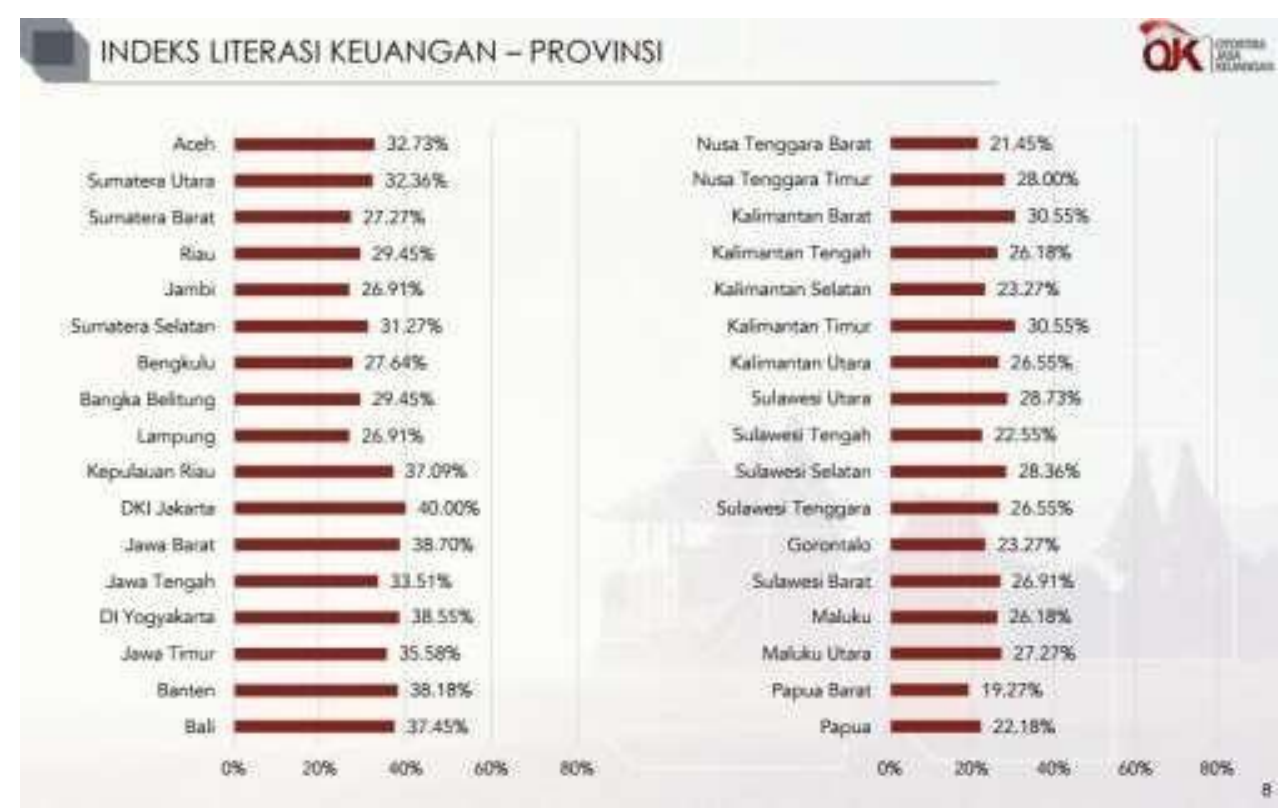

Gambar 1. Hasil Survei Tingkat Literasi Provinsi Pada Tahun 2016, OJK 


\section{Sumber: Survei Nasional Tingkat Literasi 2016, OJK}

Selain itu, mengacu pada data OJK pada tahun 2014, tingkat literasi di kalangan para pelaku UMKM hanya sebesar $15,68 \%$. Rendahnya tingkat literasi keuangan para pelaku usaha dapat menimbulkan berbagai permasalahan, antara lain manajemen hutang, pengelolaan tabungan dan kredit, dan perencanaan masa depan. Literasi keuangan yang lebih tinggi secara signifikan berdampak positif dengan penggunaan jasa keuangan yang lebih besar (Cole, et al., 2009). Akudugu, et al. (2009) dalam penelitiannya menemukan bahwa individu yang memiliki pengetahuan keuangan yang baik dan beragam dapat meningkatkan peluang keberhasilan untuk memperoleh akses pembiayaan.

Literasi keuangan akan membantu bagi pelaku usaha terkait pengelolaan usaha dimulai dari anggaran, perencanaan simpan dana usaha, serta pengetahuan dasar atas keuangan untuk mencapai tujuan keuangan usaha menurut Greenspan (2002). Salah satu daerah yang memiliki banyak UMKM di Kota depok adalah wilayah Kecamatan cinere. Posisi kec. Cinere sangat strategis dan dikenal banyak orang karena merupakan salah pintu lalu lintas wilayah jakarta - bogor.

Peran Usaha Mikro Kecil dan Menengah dinilai sangat mendukung untuk mengurangi angka kemiskinan dan pengangguran. Dapat dibuktikan UMKM menjadi salah satu program pemerintah yang memperkokoh perekonomian. Pemerintah sadar bahwa sepenuhnya kebijakan dukungan tersebut mampu mengkondisikan UMKM Indonesia yang makmur. Maka UMKM dijadikan sebagai pelopor perekonomian di Indonesia. Menjelang MEA, UMKM sudah menjadi tumpuan masyarakat dengan UMKM yang menjadi salah satu usaha yang digemari, yang terbukti penyerapan tenaga UMKM di Depok sebesar 73\% (kompasiana.com).

Pada saat ini perkembangan UMKM di Depok, Jawa Barat sangat pesat peningkatannya hingga mencapai $15 \%$. Hal ini terbukti dari survei internal pelaku UMKM. Indikatornya mulai dari sisi jumlah pelaku usaha hingga pendapatan yang meningkat. Di Depok mempunya tiga sektor yang unggul yaitu kuliner, fashion, dan handy carft (sindonews.com).

Untuk bidang kuliner, masyarakat cenderung senang mengkonsumsi jenis makanan yang bervariasi atau memiliki ciri khas tersendiri. Sedangkan bidang fashion mengalami peningkatan, karena masyarakat ingin tampil lebih kekinian dengan fashion yang dikenakannya. Begitu pun untuk bisnis handycraft juga menjadi unggul, karena banyak masyarakat yang memilih untuk menggunakan barang hasil kerajinan tangan. Barang hasil rumahan cenderung lebih menarik dibandingkan yang dihasilkan dengan menggunakan mesin. Harapan walikota Depok ke depannya seluruh jenis pelaku UMKM dapat unggul di kota Depok tidak hanya di bidang tertentu saja. Selain untuk meningkatkan pendapatan, juga sebagai informasi kepada masyarakat bahwa Depok punya berbagai jenis produk UMKM unggulan (palapanews.com). Berikut ini data perkembangan UMKM di Depok Periode 20112018: 
Tabel 1. Perkembangan Jumlah UMKM Depok Periode 2011-2018

\begin{tabular}{|c|c|c|}
\hline Tahun & Jumlah UMKM & Peningkatan jumlah UMKM (\%) \\
\hline Tahun 2011 & 125 & 25 \\
\hline Tahun 2012 & 152 & 27 \\
\hline Tahun 2013 & 177 & 25 \\
\hline Tahun 2014 & 232 & 55 \\
\hline Tahun 2015 & 272 & 40 \\
\hline Tahun 2016 & 375 & 103 \\
\hline Tahun 2017 & 459 & 84 \\
\hline Tahun 2018 & 690 & 231 \\
\hline
\end{tabular}

Sumber: kantor UMKM Depok

Berdasarkan tabel di atas dapat dilihat jumlah perkembangan UMKM di Depok setiap tahunnya mengalami peningkatan. Diketahui pada tahun 2011 sampai tahun 2018 mengalami peningkatan yang sangat pesat. Terbukti menurut Badan Penelitian Statistik (BPS) kota Depok bahwa penduduk miskin di Depok, memang mengalami penurunan mencapai 0,14 persen. Namun, biaya hidup di Depok cukup mahal. Garis kemiskinan di Depok urutan ke dua se-jawa barat, karena untuk hidup yang layak di kota tersebut membutuhkan biaya yang cukup tinggi (tempo.com). Biaya hidup rata-rata penduduk kota depok berkisar Rp.6.300.000,00 per bulan, sedangkan upah minimum kota depok yang di patok sebesar Rp.3.000.000,00 per bulan.

Jumlah data UMKM di Cinere adalah 30 UMKM dengan rata - rata omset penjualan UMKM yang relatif kecil, Sedangkan Badan Penelitian Statistik mengatakan biaya hidup di Depok cukup mahal sebesar Rp. 6.300.000,00 per bulan, sehingga pendapatan yang diperoleh pelaku UMKM Cinere tidak dapat menutupi kebutuhan sehari-hari (amp.dw.com).

Perekonomian yang semakin sulit, gaya hidup yang semakin berubah dari zaman ke zaman, kebutuhan individu semakin banyak tetapi sumber pendapatan yang minim atau kecil menuntut Para pelaku umkm harus mempunyai perilaku keuangan yang baik dan dapat mengambil keputusan yang tepat dalam mengatur keuangan, Agar kebutuhan dalam keluarga maupun diri sendiri dapat terpenuhi. Pengetahuan keuangan menjadi hal yang tidak terpisahkan dalam kehidupan karena merupakan alat yang berguna untuk membuat keputusan keuangan yang bijak. Dengan adanya pengetahuan keuangan akan membantu individu dalam mengatur perencanaan keuangan pribadi, sehingga individu tersebut bisa memaksimalkan nilai waktu uang dan keuntungan yang diperoleh oleh individu akan semakin besar dan akan meningkatkan taraf kehidupannya.

Pelaku UMKM tidak hanya mengandalkan pendapatan dan pengetahuan keuangan saja, kecuali individu dapat mengendalikan dirinya sendiri dalam situasi yang terjadi. Individu yang memiliki kepercayaan pada diri sendiri yang lebih besar dan bisa mengendalikan diri pada nasibnya sendiri disebut dengan lokus pengendalian internal. Sementara individu yang memiliki kepercayaan bahwa lingkunganlah yang mempunyai kontrol terhadap nasib atau kejadian yang terjadi dalam kehidupannya dikatakan individu tersebut memiliki lokus pengendalian eksternal. Dengan demikian, semakin tinggi tingkat lokus pengendalian internal yang dimiliki oleh individu maka perilaku keuangan individu akan semakin baik.

Berdasarkan hasil analisa di lapangan, kondisi UMKM di wilayah Kecamatan Cinere saat ini masih memiliki keterbatasan dengan berbagai permasalahan, baik kelembagaan 
usaha, maupun permodalan, yang masih merupakan faktor pembatas ruang gerak UMKM. Namun bila dipelajari permasalahan yang ada, pada dasarnya secara umum terletak pada keterbatasan SDM dari pelaku UMKM itu sendiri. Keterbatasan yang dialami tersebut diantaranya dalam permodalan, pengelolaan keuangan perusahaan, kurang mantapnya pelaksanaan manajemen keuangan, terbatasnya akses informasi dan teknologi, serta sempitnya lingkup pasar.

Selain itu sebagian besar pelaku UMKM di wilayah Kecamatan Cinere belum mengetahui tata kelola keuangan dengan baik, dari segi pengetahuan, pendidikan maupun pendapatan. Keterbatasan para pelaku UMKM di Kecamatan Cinere tersebut disebabkan oleh karena kurangnya pemahaman mereka terhadap literasi keuangan, sehingga para pelaku UMKM di wilayah tersebut belum dapat menerapkan akuntansi dalam kegiatan usahanya.

Pada saat ini, UMKM yang berada di wilayah Kecamatan Cinere tersebut melakukan pencatatan keuangan berupa pemasukan dan pengeluaran hanya dari bukti-bukti transaksi penjualan dan pembelian. Padahal, UMKM tersebut melakukan produksi setiap hari dan menghasilkan hasil produksi atau barang hingga ratusan unit setiap harinya, serta tidak sedikit pelanggan atau distributor yang melakukan permintaan barang. Apabila pemilik memperoleh pendapatan dari pelanggan, maka langsung digunakan untuk membeli bahan baku rutin setiap bulannya. Namun, hampir semua pelanggan membeli barang kepada produsen UMKM tersebut secara kredit tanpa ada penentuan waktu pelunasan. Sehingga, pemilik sering merasa kesulitan dalam membeli bahan baku karena keterbatasan modal yang dimiliki. Hal tersebut menjadi kendala bagi UMKM di wilayah Kecamatan Cinere untuk mengembangkan usahanya.

Berdasarkan uraian latar belakang diatas, dapat disimpulkan bahwa pemahaman terhadap literasi keuangan sangat dibutuhkan oleh para pelaku usaha, tidak terkecuali pelaku UMKM agar dapat melakukan pengelolaan keuangan dengan baik dan benar. Didalam literasi keuangan terdapat pengetahuan keuangan, perencanaan keuangan dan pengelolaan keuangan yang dapat digunakan oleh para pelaku usaha agar mampu meningkatkan pertumbuhan perusahaan.

Penelitian yang dilakukan oleh Anggraeni, 2015 terkait pengaruh literasi keuangan terhadap pengelolaan keuangan menunjukkan hasil bahwa tingkat literasi keuangan dari pemilik usaha rendah sehingga berpengaruh terhadap kemampuan mengelola keuangan. Hal ini tercermin dari hasil sikap keuangan pemilik usaha dimana mereka sebatas mencatat penerimaan dan pengeluaran keuangan usaha tanpa disertai dengan penyimpanan dokumen pendukung.

Sedangkan penelitian Suryani dan Ramadhan, 2017 menunjukkan bahwa tingkat literasi keuangan pelaku UMKM adalah sedang (57,9\%). Variabel yang mempengaruhi tingkat literasi keuangan pelaku usaha adalah perbedaan pendidikan dan pendapatan. Siahaan, 2013 menunjukkan bahwa literasi keuangan, perencanaan keuangan, dan control diri secara simultan mempengaruhi perilaku pengelolaan keuangan, kemudian literasi keuangan dan control diri tidak secara langsung mempengaruhi perilaku pengelolaan keuangan. Terkait dengan research gap dan pembahasan di atas, pada penelitian ini, penulis tertarik untuk menguji signifikansi pengaruh tingkat literasi keuangan terhadap pengelolaan keuangan pada pelaku UMKM, yaitu di wilayah Kecamatan Cinere. Dengaxn demikian penelitian ini 
berjudul "Pengaruh Tingkat Literasi Keuangan terhadap Pengelolaan Keuangan Pada Pelaku UMKM Kecamatan Cinere, Depok".

\section{KAJIAN PUSTAKA \\ LITERASI KEUANGAN}

Lusardi (2012) menyatakan bahwa literasi keuangan ialah suatu keterampilan yang harus dikuasai oleh setiap individu untuk memperbaiki taraf hidupnya dengan upaya pemahaman terhadap perencanaan dan pengalokasian sumber daya keuangan yang tepat dan efisien. Selain itu Huston (2010) mendefinisikan literasi keuangan sebagai keahlian yang dimiliki oleh individu dengan kemampuannya untuk mengelola pendapatannya agar tercapai peningkatan kesejahteraan finansial.

Literasi keuangan yang menjadi hal dasar yang harus dipahami dan dikuasai oleh setiap individu karena berpengaruh terhadap kondisi keuangan seseorang serta memiliki dampak terhadap pengambilan keputusan ekonomi yang baik dan tepat (Anggraeni, 2015).

Definisi literasi keuangan menurut surat edaran Otoritas Jasa Keuangan (OJK) pada tahun 2014 menyatakan bahwa literasi keuangan merupakan rangkaian proses atau aktivitas untuk meningkatkan pengetahuan, keterampilan, dan keyakianan konsumen dan masyarakat luas sehingga mereka memiliki kemampuan untuk mengelola keuangan dengan lebih baik. Literasi keuangan diharapkan oleh OJK memberikan manfaat kepada masyarakat luas seperti kemampuan untuk memilih produk dan layanan jasa keuangan sesuai dengan kebutuhan, kemampuan membuat perencanaan keuangan yang baik, dan terhindar dari investasi yang tidak jelas. OJK membagi tingkat literasi keuangan masyarakat Indonesia menjadi empat, yaitu :

1. Well literate, yaitu memiliki pengetahuan dan keyakinan tentang lembaga jasa keuangan serta produk jasa keuangan, termasuk fitur, manfaat dan risiko, hak dan kewajiban terkait produk dan jasa keuangan, serta memiliki keterampilan dalam menggunakan produk dan jasa keuangan.

2. Sufficient literate, yakni memiliki pengetahuan dan keyakinan tentang lembaga jasa keuangan serta produk dan jasa keuangan, termasuk fitur, manfaat dan risiko, hak dan kewajiban terkait produk dan jasa keuangan.

3. Less literate, yaitu hanya memiliki pengetahuan tentang lembaga jasa keuangan, produk dan jasa keuangan.

4. Not literate, yaitu tidak memiliki pengetahuan dan keyakinan terhadap lembaga jasa keuangan serta produk dan jasa keuangan, serta tidak memiliki keterampilan dalam menggunakan produk dan jasa keuangan.

Chen dan Volpe (1998) dalam Mendari dan kewal (2014) membagi literasi keuangan menjadi 4 aspek dalam pemahaman terhadap pengelolaan keuangan pribadi yang meliputi :

1. General Personal Finance, yaitu kemampuan untuk memahami sesuatu yang berhubungan dengan pengetahuan dasar tentang keuangan pribadi. Rasyid (2012) menjelaskan bahwa general personal finance adalah pengetahuan tentang keuangan pribadi secara umum. Sedangkan manajemen keuangan adalah suatu proses perencanaan, analisa, dan pengendalian kegiatan keuangan. 
2. Saving and borrowing, yaitu kemampuan untuk memahami hal-hal yang berkaitan dengan tabungan dan pinjaman.

3. Insurance, pemahaman individu tentang pengetahuan dasar asuransi dan produk-produk asuransi seperti asuransi pendidikan dan asuransi jiwa.

4. Invesment, yaitu kemampuan dasar untuk memahami sesuatu yang berkaitan tentang suku bunga, risiko investasi, pasar modal, rekasa dana, dan deposito.

Remund (2010) dalam Margaretha dan Pambudhi (2015:76) menjelaskan bahwasannya dalam literasi keuangan memiliki lima domain yaitu:

1. Pengetahuan tentang konsep keuangan.

2. Kemampuan untuk berkomunikasi tentang konsep keuangan.

3. Kemampuan untuk mengelola keuangan pribadi.

4. Kemampuan dalam membuat keputusan keuangan.

5. Keyakinan untuk membuat perencanaan keuangan masa depan.

\section{PENGELOLAAN KEUANGAN UMKM}

Menurut Husnan (2000) manajemen keuangan atau pengelolaan keuangan adalah pengaturan kegiatan keuangan dalam suatu organisasi. Manajemen keuangan menyangkut kegiatan perencanaan usaha, pengelolaan kas dan pengendalian kegiatan keuangan. Manajemen keuangan ini dilakukan untuk mengatur keuangan dalam usaha yang berukuran kecil, mulai dari pendanaan, manajemen kas, dan kebutuhan untuk pengembangan usahanya.

Kebutuhan dari internal perusahaan akan laporan keuangan sebagai alat evaluasi kinerja, untuk membantu pengambilan keputusan, sebagai syarat pengajuan kredit ke bank atau kreditor, sedangkan kebutuhan eksternal sebagai pertanggungjawaban perusahaan terhadap calon atau investor/kreditor, pertanggungjawaban kepada masyarakat.

Dikutip dari website berdesa.com pengelolaan berguna sebagai pengendali dalam membelanjakan uang, maka akan menghasilkan keuntungan, sehingga mampu untuk membiayai usaha. Pengelolaan keuangan ini perlu diterapkan oleh pelaku dalam UMKM diharapkan nantinya akan mengurangi risiko kerugian usaha. Berikut saran dalam pengelolaan keuangan untuk UMKM:

a. Memisahkan uang milik pribadi dan uang usaha. Kesalahan yang sering terjadi dan paling sering dilakukan oleh pelaku UMKM adalah mencampurkan uang usaha dengan uang pribadi. Risiko apabila tidak ada pemisahan antara uang pribadi dan usaha adalah penggunaan uang pribadi yang berlebih, maka memisahkan secara fisik uang pribadi dan uang usaha sangatlah penting.

b. Membuat perencanaan pembelanjaan uang. Rencanakan penggunaan uang dengan sebaik mungkin. Jangan pernah mempergunakan uang tanpa perencanaan yang jelas, karena ada

c. kemungkinan menemui keadaan kekurangan dana bila tidak ada perencanaan yang jelas. Menyesuaikan rencana pengeluaran dengan target penjualan dan penerimaan kas. Lakukan analisis cost and benefit untuk memastikan bahwa pengeluaran yang dilakukan tidak sia-sia dan memberikan keuntungan yang jelas. 
d. Membuat buku catatan keuangan. Ingatan setiap orang tidak selalu kuat dan bahkan sangat terbatas, maka mengelola keuangan sebuah usaha haruslah dengan catatan yang lengkap. Minimal memiliki buku kas masuk dan buku kas keluar yang mencatat arus keluar masuknya uang, selain itu mencocokkan jumlah fisik uang dengan catatan Anda. Mencatat hutang-piutang serta aset-aset yang Anda miliki. Apabila mampu, dapat menggunakan sistem komputer untuk memudahkan proses pencatatan.

e. Menghitung keuntungan dengan benar. Menghitung keuntungan dengan tepat sama pentingnya dengan menghasilkan keuntungan itu sendiri. Bagian paling penting dalam menghitung keuntungan adalah menghitung biaya-biaya. Sebagian besar biaya dapat diketahui karena menggunakan pembayaran tunai. Sebagian yang lain berupa uang kas, yaitu penyusutan dan amortasi. Sebagian lagi belum terjadi namun perlu dicadangkan untuk pengeluaran di masa mendatang, contohnya pajak dan bunga.

f. Memutar arus kas. Manajemen keuangan juga meliputi bagaimana untuk mengelola hutang, piutang dan persediaan. Pemutaran kas melambat jika termin penjualan kredit lebih lama daripada harga belinya, atau jika Anda harus menyimpan persediaan barang dagangan. Usahakan termin penjualan kredit sama dengan pembelian kredit.

g. Melakukan pengendalian terhadap harta, utang, dan modal. Lakukan pemeriksaan terhadap persediaan yang ada di gudang secara berkala dan memastikan semuanya dalam keadaan lengkap dan baik- baik saja. Hal yang sama juga perlu dilakukan terhadappiutang-piutang kepada pembeli serta tagihan-tagihan dari supplier.

h. Menyisihkan keuntungan untuk pengembangan usaha. Menikmati keuntungan dari usaha tentu saja adalah hal yang wajar, namun sisihkanlah sebagian keuntungan yang Anda miliki untuk mengembangkan usaha, atau untuk menjaga kelangsungan usaha. Semakin besar sebuah usaha, maka akan semakin kompleks pula cara pengelolaan keuangannya. UMKM yang sudah memiliki kreditor dan investor maka semakin tinggi pula tuntutan untuk memiliki catatan keuangan yang baik.

\section{METODE PENELITIAN}

Penelitian ini menggunakan teknik analis kuantitatif dan kualitatif yang fokus pada kondisi lapangan dan masyarakat. Pendekatan serta tehnik Analisa pada penelitian ini menggunakan pendekatan rasionalistik dengan memperhatikan terlebih dahulu hal-hal umum menuju ke hal khusus sebagai dasar analisa suatu masalah. Jenis penelitian yang digunakan adalah metode kuantitatif yang fokus pada kondisi di lapangan. Sesuai wilayah penelitian, yaitu Kec. Cinere. Teknik penelitian kuantitatif menekankan pada aspek pengukuran secara obyektif terhadap fenomena sosial. Untuk dapat melakukan pengukuran, setiap fenomena sosial di jabarkan kedalam beberapa komponen masalah, variabel dan indikator. dengan sumber data primer yang diperoleh dari hasil penyebaran kuesioner menggunakan skala likert yang diberikan kepada 50 warga Kec. Cinere-Depok dengan alat analisis yang digunakan yaitu SmartPLS.

\section{HASIL DAN PEMBAHASAN}

Berdasarkan pengujian yang dilakukan, diketahui bahwa kuisioner dinyatakan valid dan reliabel, dengan nilai validitas 0,5 dan nilai realibilitas diatas nilai 0,7. Selanjutnya, 
diperoleh pula hasil uji $\mathrm{R}^{2}$ dengan nilai $\mathrm{R}^{2}$ adjusted sebesar 0,850 atau $85 \%$ yang artinya bahwa pada masing-masing variabel yaitu variabel literasi keuangan dapat emnerangkan variabel pengelolaan keuangan . Kemudian diperoleh pula hasil nilai koefesien Analisis Jalur dimana didalamya terdapat hasil uji t beserta nilai original sample dan nilai signifikansi.

Tabel 2. Hasil Uji t-stastistik

\begin{tabular}{lccc}
\hline & Original Sample & T Statistics & P Values \\
\hline $\begin{array}{l}\text { Literasi Keuangan -> Pengelolaan } \\
\text { Keuangan }\end{array}$ & 0.173 & 2.258 & 0.024 \\
\hline
\end{tabular}

Sumber: Hasil Output PLS 3.2.7

Berdasarkan tabel diatas dapat dilihat bahwa hasil pengaruh Literasi Keuangan terhadap pengelolaan keuangan memiliki nilai original sample sebesar 0.173 dan menunjukkan nilai $t_{\text {hitung }} 2.258>\mathrm{t}_{\text {tabel }} 2.012$ dan nilai $\mathrm{P}$ Value sebesar $0,024<0,05$. Hal tersebut menunjukan bahwa Literasi Keunagan berpengaruh signifikan terhadap pengelolaan keuangan.

Berdasarkan hasil penelitian ini bahwa hasil pengujian hipotesis menunjukkan literasi keuangan berpengaruh terhadap pengelolaan keuangan. Hal ini ditunjukkan denan nilai koefisien sebesar 0.173 dan menunjukkan nilai thitung $2.258>$ ttabel 2.012 dan nilai P Value sebesar 0,024<0,05. Sehingga dapat diambil kesimpulan bahwa literasi keuangan berpengaruh signifikan terhadap pegelolaan keuangan atau dengan kata lain H1 diterima.

Hal tersebut dapat dibuktikan dengan beberapa penyataan indikator yang memberikan pengaruh yang kuat untuk literasi keuangan yaitu berkomunikasi tentang konsep keuangan kepada perusahaan yang bergerak dibidang keuangan, pelaku UMKM Memiliki kemampuan untuk mengelola keuangan pribadi dan Pelaku UMKM Memiliki kemampuan untuk menggunakan agency untuk memperbaiki keuangan. Dalam hal ini untuk meningkatkan literasi keuangan dengan memberikan manfaat kepada masyarakat luas seperti kemampuan untuk memilih produk dan layanan jasa keuangan sesuai dengan kebutuhan, kemampuan membuat perencanaan keuangan yang baik, dan terhindar dari investasi yang tidak jelas.

Dapat diartikan bahwa Pelaku UMKM di wilayah Cinere-Depok menyadai pentingnya literasi keuangan dalam pengelolaan keuangan usahanya. Jika dilihat dari indikator hal tersebut mampu meningkatkan pengelolaan keuangan. Penelitian ini sejalan dengan penelitian yang dilakukan oleh Anggraeni, (2015);Sanistasya dkk (2019) dan Suryani dan Ramadhan, 2017 menyatakan bahwa literasi keuangan berpengaruh signifikan terhadap pengelolaan keuangan.

\section{KESIMPULAN DAN SARAN}

Berdasarkan hasil analisis dan pembahasan yang telah diuraikan pada bab- bab sebelumnya dan melalui analisis Partial Least Square (PLS) mengenai pengaruh literasi keuangan terhadap pengelolaan keuangan pada Pelaku UMKM di Wilayah Kecamatan Cinere-Depok serta pengujian yang telah dilakukan maka dapat disimpulkan bahwa literasi keuangan berpengaruh terhadap pengelolaan keuangan pada Pelaku UMKM Kuliner di Kecamatan Cinere -Depok. 
Saran yang dapat diberikan oleh peneliti adalah Pada variabel literasi keuangan berdasarkan indikator pengetahuan tentang konsep keuangan, agar para pelaku usaha selalu mempertahankan serta memperbaiki dalam pembuatan laporan usahanya.

\section{DAFTAR RUJUKAN}

Amp.dw.com, (2016). Diakses 14 Maret 2016, Dari https://www.google.co.id/amp/amp.dw.comid/inilah-kota-termahal - di-indonesia/g19228896?espv=1

Chen, H \& Volpe, RP. 1998. "An Analysis of Personal Financial Literacy among College Students." Financial Services Review, 7(2), 107-128.

Dinas Koperasi UMKM dan Pasar kota Depok, (2017). Data Perkembangan UMKM periode 2008 - 2015, Depok: Balai Walikota Depok.

Ghozali, I. (2014). Structural equation modeling, Semarang: Universitas Dipenogoro.

Husnan, Suad. 2005. Dasar-Dasar Teori Portofolio dan Analisis Sekuritas. Edisi keempat. Yogyakarta: UPP AMD YKPN

Ida. \& Dwinta, S.Y. (2010). „Pengaruh locus of control, financial knowlegde, Income terhadap financial management behavior",Journal bussiness and accounting, Vol.12 No.3, Desember 2010, hlm 131-144.

Kasmir (2010). Pengantar manajemen keuangan. Jakarta : kencana persada media group.

Kuswadi. 2005. Meningkatkan Laba Melalui Pendekatan Akuntansi Keuangan dan Akuntansi Biaya. PT. Elex Media Komputindo, Jakarta.

Layyinaturrobaniyah \& Wa Ode Zusnita Muizu. 2017. Pendampingan Pengelolaan Keuangan Usaha Mikro Di Desa Purwadadi Barat Dan Pasirbungur Kabupaten Subang. Pekbis Jurnal, Vol.9, No.2, Universitas Padjadjaran.

Lusardi, A dan O.S. Mitchell. 2014. The Economic Importance of Financial Literacy: Theory and Evidence. Journal of Economi

Lusardi, A., \& Mitchell, O. s. (2007). baby boomer retirement security: the roles of planning. financial literacy, and housing wealth. journal of monetary economics, 54(!), 205-224, 7.

Muraga, K.P, dan John, N. 2015. Effects of financial literacy on performance of youth led entreprises: a case of equity group foundation training program in Kiambu county. International Journal: Applied Economic. Vol 5 No 1. Hal 199-197.

Undang-Undang Republik Indonesia Nomor 20 Tahun 2008 Tentang Usaha Mikro, Kecil, dan Menengah dan Undang-Undang Republik Indonesia Nomer 21 Tahun 2008 Tentang Perbankan Syari'ah. 